\title{
Sprawozdanie z prac w Papieskim Instytucie Studiów Kościelnych (2016)
}

W ramach pomocy instytucjom polonijnym z ramienia Naczelnej Dyrekcji Archiwów Państwowych w Warszawie przebywałam dwukrotnie w dniach 29 czerwca - 15 lipca oraz 1-12 października 2016 r. w Papieskim Instytucie Studiów Kościelnych w Rzymie. Celem wyjazdów było kontynuowanie porządkowania i zabezpieczania zbiorów w instytucjach polonijnych.

W trakcie pierwszego pobytu uporządkowano (wspólnie z dr Lidią Potykanowicz-Sudą z Archiwum Państwowego w Gdańsku) dopływy do zespołów: Spuścizna Stanisława Kościałkowskiego i Spuścizna Karola Kleszczyńskiego. Odnalezione w Instytucie materiały zawierały głównie broszury i książki z instytutów kierowanych przez prof. S. Kościałkowskiego (Towarzystwa Studiów Irańskich i Instytutu Polskiego w Bejrucie) oraz inne książki. Publikacje te zostały włączone do Biblioteki Instytutu z odpowiednimi adnotacjami.

W trakcie dalszych prac skoncentrowano się na 4 segregatorach dokumentacji aktowej, które stanowiły spuściznę K. Kleszczyńskiego. Została ona usystematyzowana na grupy rzeczowe pokrewne treściowo, następnie uformowano z nich jednostki archiwalne, nadając dokumentom porządek chronologiczny. W dalszej kolejności uporządkowano fotografie, także systematyzując je na grupy pokrewne treściowo. Ponadto sporządzono ewidencję pamiątek osobistych po K. Kleszczyńskim (m.in. medale, odznaczenia, dyplomy, zbiór widokówek, rycin, kaset magnetofonowych). Całość uporządkowanych materiałów archiwalnych zapakowano w pudła z tektury bezkwasowej (57 j.a., ok. 2 mb). Jednostki wpisano do bazy IZA 6.1 oraz uzupełniono bazę Sezam dla zespołu.

Dodatkowo przepakowano w pudła $\mathrm{z}$ tektury bezkwasowej i osygnowano 3 zespoły archiwalne, co łącznie stanowi 7,30 mb. Następnie założono ewidencję archiwum Instytutu dla 7 zespołów (wydrukowano inwentarze wraz z indeksami i opisano segregatory).

W trakcie drugiego pobytu uporządkowano materiały dotyczące wystaw objazdowych: „La chiesa del silenzio”, „Quarant'anni di vita sovietica” oraz „50 anni di comunismo” i „Mostra documentaria della realtà comunista”. Dokumentacja ta została dołączona do spuścizny K. Kleszczyńskiego. Materiały osygnowano i umieszczono w pudłach z tektury bezkwasowej (106 j.a., 1,26 mb). Następnie jednostki wpisano do bazy 6.1. 